Golden Gate University School of Law GGU Law Digital Commons

$11-7-2011$

\title{
Redevelopment Agency V BNSF Ry. (9th Cir 2011) 643 F3d 668
}

Roger Bernhardt

Golden Gate University School of Law, rbernhardt@ggu.edu

Follow this and additional works at: http://digitalcommons.law.ggu.edu/pubs

Part of the Property Law and Real Estate Commons

\section{Recommended Citation}

Bernhardt, Roger, "Redevelopment Agency V BNSF Ry. (9th Cir 2011) 643 F3d 668" (2011). Publications. Paper 471.

http://digitalcommons.law.ggu.edu/pubs/471

This Article is brought to you for free and open access by the Faculty Scholarship at GGU Law Digital Commons. It has been accepted for inclusion in Publications by an authorized administrator of GGU Law Digital Commons. For more information, please contact jischer@ggu.edu. 
Redevelopment Agency v BNSF Ry. (9th Cir 2011) 643 F3d 668

Railroads were not liable for petroleum contamination discovered on property they had previously owned. They were only passively, remotely, and unknowingly connected with petroleum spills. Their innocent maintenance of french drain that facilitated migration of petroleum to property did not trigger liability.

In 1968, two railroads agreed to move their tracks to a nearby state-owned property so that the State of California could build a new freeway interchange. The railroads planned and approved the grading and drainage improvements on the site, which the state made, including the installation of a french drain beneath the roadbed. (Note a factual inconsistency: Later in the opinion, the court states that the railroads, not the state, installed the french drain.) The railroads began using the new track in 1970. In 1983, the state deeded the property containing the new tracks to the railroads.

In 1988, the railroads sold the property to the local redevelopment agency (RDA). In 2004, the RDA sold a portion of the property to a commercial developer. The developer found contaminated soils and groundwater on the site, caused by petroleum spills at a nearby industrial site during the early 1970s. The petroleum migrated to the property via the underground french drain. The RDA sued the railroads, contending they were liable for the contamination under nuisance principles and under the Polanco Redevelopment Act (Health \& S C §§33459-33459.8). The RDA moved for summary judgment, which the district court granted in part (on nuisance) and denied in part (on statutory liability). On appeal, the Ninth Circuit held that the railroads were not liable under any theory for the contaminated soil and groundwater.

The railroads did not create or assist in the creation of a nuisance because they did not actively generate or permit the nuisance condition. The simple fact that the petroleum migrated to the property through the french drain maintained by the railroads amounted to a passive, attenuated causal connection with the resulting contamination, not an active connection that would trigger nuisance liability. Nor did the railroads incur nuisance liability as possessors of the property when the contamination occurred. Such liability would arise only if the railroads knew or should have known about the contamination. Notably, no one discovered the contamination until 16 years after the railroads had sold the property. The railroads were not responsible for subsurface inspections because "it is untenable that a possessor of land, simply because his neighbor is a potential polluter, thereby becomes responsible for investigating the subsurface in order to discover and control his neighbor's pollution.” 643 F3d at 676. Although the railroads had a duty to maintain the french drain, they fulfilled that responsibility by making sure that the water drained as necessary. 
The railroads also were not responsible for the contamination under the Polanco Act. They were not involved at all with the initial petroleum spills. Their involvement with the actual contamination was "was entirely passive and unknowing," resting simply on the fact that they maintained the french drain, which would not trigger liability under Wat C §13304(a). An owner or an operator may be held liable under the Polanco Act’s Comprehensive Environmental Response, Compensation, and Liability Act (CERCLA) provision for petroleum contamination of property, but the railroads did not receive title to the property until 1983. Nor could the railroads be considered equitable owners of the property at the time of the contamination, because the agreement conveying the railway rights-of-way did not constitute a valid land sales contract conveying a defined, fee simple interest in the property.

The fact that the railroads had an easement on the property did not trigger CERCLA liability under 42 USC §9607(a), particularly because the french drain was intended to relay water, not petroleum, and because the railroads did not conduct any operations connected with petroleum production or use.

The Editor's Take: While every court in the country would probably reach the same outcome, California law makes a court get there by some oddly unique reasoning.

Courts everywhere else in the United States would have simply dismissed the nuisance claim against the railroads on the ground that the plaintiff was suing as a successor rather than as a neighbor of the defendant. Nuisance law regulates relations with neighbors, not successor owners (who can handle their concerns by contracts and deeds). See Moore $v$ Texaco (10th Cir 2001) 244 F3d 1229. Only California, as far as I know, has so broadened the law of nuisance as to let current owners sue former owners of the same property for how those former owners behaved while they were in possession. See Mangini v Aerojet Gen. Corp. (1996) 230 CA3d 1125, 281 CR 827, reported at 19 CEB RPLR 134 (May 1996).

Because nuisance law was involved in only one count of the complaint, the plaintiff's other theories could well have survived the fact that the defendant once owned the same (rather than some other) property of the plaintiff. CERCLA law would let a current owner sue a former owner or operator for polluting, so the court's holding here is that a railroad using a right-of-way over a polluting french drain is neither owner nor operator nor polluter, even though it planned and approved the drain, as long as that drain was intended to carry water off the land rather than to bring oil onto the land. But would it also be held universally that a neighbor who builds a french drain on his land to carry water off his parcel B is not liable to the owner of parcel C, if oil from adjacent parcel A backs up and migrates through the drain over parcel B and onto to parcel C? Litigating that issue could be even more expensive than just removing the contaminated soil.Roger Bernhardt 